\title{
A2 Milk Enhances Dynamic Muscle Function Following Repeated Sprint Exercise, a Possible Ergogenic Aid for A1-Protein Intolerant Athletes?
}

\author{
Ben Kirk ${ }^{1, *}$, Jade Mitchell ${ }^{2}$, Matthew Jackson ${ }^{1}$, Farzad Amirabdollahian ${ }^{1}$, \\ Omid Alizadehkhaiyat ${ }^{1}$ and Tom Clifford ${ }^{2}$ \\ 1 School of Health Sciences, Liverpool Hope University, Hope Park, Liverpool L16 9JD, UK; \\ jacksom1@hope.ac.uk (M.J.); amirabf@hope.ac.uk (F.A.); alizado@hope.ac.uk (O.A.) \\ 2 Department of Sport, Exercise \& Rehabilitation, Northumbria University, Newcastle Upon Tyne NE1 8ST, \\ UK; j.mitchell@nutritionsociety.org (J.M.); tom.clifford@northumbria.ac.uk (T.C.) \\ * Correspondence: kirkb@hope.ac.uk; Tel.: +44-0151-291-3815
}

Received: 6 December 2016; Accepted: 24 January 2017; Published: 28 January 2017

\begin{abstract}
Hyperaminoacidemia following ingestion of cows-milk may stimulate muscle anabolism and attenuate exercise-induced muscle damage (EIMD). However, as dairy-intolerant athletes do not obtain the reported benefits from milk-based products, A2 milk may offer a suitable alternative as it lacks the A1-protein. This study aimed to determine the effect of A2 milk on recovery from a sports-specific muscle damage model. Twenty-one male team sport players were allocated to three independent groups: A2 milk $(n=7)$, regular milk $(n=7)$, and placebo (PLA) $(n=7)$. Immediately following muscle-damaging exercise, participants consumed either A2 milk, regular milk or PLA (500 mL each). Visual analogue scale (muscle soreness), maximal voluntary isometric contraction (MVIC), countermovement jump (CMJ) and 20-m sprint were measured prior to and 24, 48, and $72 \mathrm{~h}$ post EIMD. At $48 \mathrm{~h}$ post-EIMD, CMJ and 20-m sprint recovered quicker in A2 (33.4 \pm 6.6 and $3.3 \pm 0.1$, respectively) and regular milk (33.1 \pm 7.1 and $3.3 \pm 0.3$, respectively) vs. PLA (29.2 \pm 3.6 and $3.6 \pm 0.3$, respectively) $(p<0.05)$. Relative to baseline, decrements in $48 \mathrm{~h} \mathrm{CMJ}$ and 20-m sprint were minimised in A2 (by 7.2 and 5.1\%, respectively) and regular milk (by 6.3 and $5.2 \%$, respectively) vs. PLA. There was a trend for milk treatments to attenuate decrements in MVIC, however statistical significance was not reached $(p=0.069)$. Milk treatments had no apparent effect on muscle soreness $(p=0.152)$. Following muscle-damaging exercise, ingestion of $500 \mathrm{~mL}$ of $\mathrm{A} 2$ or regular milk can limit decrements in dynamic muscle function in male athletes, thus hastening recovery and improving subsequent performance. The findings propose A2 milk as an ergogenic aid following EIMD, and may offer an alternative to athletes intolerant to the A1 protein.
\end{abstract}

Keywords: A2 milk; exercise recovery; muscle damage; team sports; muscle function

\section{Introduction}

Participation in unaccustomed eccentric exercise often causes exercise-induced muscle damage (EIMD) [1-3]. Physical activity with a large eccentric component includes resistance training, sprinting and plyometrics [4], all of which are common amongst sporting activities [5]. The exact causes of EIMD are ill-understood, but it is thought to be initiated by mechanical disruption of the myofibrils, which results in ultrastructural damage to the whole muscle cell [6,7]. It has been proposed that muscle function after EIMD is compromised through damage to the excitation-contraction (EC) coupling system, which is essential for muscle contraction and force output [8,9]. Mechanical damage coupled with the disruption of the EC coupling system is thought to activate a cascade of intracellular reactions such as an influx of calcium $\left(\mathrm{Ca}^{2+}\right)$ into the cytosol that precipitate an acute phase inflammatory 
response [7]. In conjunction with other biochemical changes, such as increased reactive oxygen species (ROS) production [10], the inflammatory response might further degrade the muscle architecture in the days following muscle-damaging exercise [11,12]. Such changes can reduce the ability to generate power, evoke muscle pain (delayed onset muscle soreness, DOMS) and increase the release of intramuscular enzymes (i.e., creatine kinase) $[6,13,14]$. These symptoms generally peak $48 \mathrm{~h}$ after exercise [15] but can persist for 5-7 days [16,17]. This is particularly problematic in team-sports, where athletes are often required to train and/or compete on multiple occasions during a weekly cycle $[18,19]$. As a consequence, subsequent exercise performance might be impaired, and the propensity for injury increased [20].

Examples of the detrimental consequences of EIMD on exercise performance have been well documented [21]; twelve resistance-trained males demonstrated a $22.5 \%$ reduction in vertical jump height, and a 3-fold increase in muscle soreness after a bout of muscle-damaging drop jumps [22]. In a recent study with team-sports trained players, power generating ability (as measured by counter movement jump performance and reactive strength index) was reduced for up to $72 \mathrm{~h}$ after a single bout of repeated sprint exercise [1]. Such prolonged impairments in muscle function after muscle-damaging exercise are likely to negatively affect an athlete's ability to perform in real-world sporting situations (i.e., competitions or training) [5,19].

Numerous studies have suggested that protein (PRO)-rich supplements are capable of attenuating indices of EIMD. The effects of whey PRO [23], casein PRO [24], leucine [25], and branched-chain amino acids (AA) [22] have been investigated for their ability to attenuate EIMD and hasten recovery, with many suggesting favourable effects [22-24].

More recently, a combination of PRO-carbohydrate $(\mathrm{CHO})$ beverages such as dairy-milk [26], which have a favourable digestible and indispensable amino-acid score (DIAAS) > 1.0 [27], have expedited recovery of muscle function following eccentric-heavy exercise [28]. Dairy milk by mass contains $\sim 80 \%$ casein and $\sim 20 \%$ whey PRO, providing an advantageous balance of slow and fast digesting AA to the muscle for protein turnover [29]. By increasing AA availability, in particular leucine, milk activates anabolic signalling of mammalian target of rapamycin (mTOR), the key metabolic regulator for muscle PRO synthesis [30]. Post-exercise feeding of PRO and CHO can also favourably raise blood insulin levels from $\sim 5$ to $30 \mathrm{~m} / \mathrm{UL}$ [31], providing an ideal insulinogenic environment which may suppress the breakdown of skeletal muscle via the ubiquitin proteasome pathway [28,32]. This increase in insulin action is attributed to increased microvascular perfusion [33].

In a series of studies [26,34-36] milk supplementation post-eccentric exercise was shown to attenuate symptoms of EIMD, such as muscle soreness and deficits in muscle function. At present, the mechanisms underlying reduction in EIMD with milk are unclear. However, one possible mechanistic explanation is that milk inhibits the activity of calpains and other degradative pathways upregulated after muscle-damaging exercise [37-39]. This, in turn, preserves the integrity of the muscle cell, especially the proteins responsible for force generation and transmission. Irrespective of the exact mechanisms, the above data suggest that milk is a promising recovery intervention after strenuous exercise [29]. However, for athletes who are intolerant to lactose and/or the A1 beta-casein PRO, found in regular milk, these ergogenic benefits remain elusive, including: PROs for muscle recovery, $\mathrm{CHO}$ for glycogen resynthesise, and electrolyte and vitamin replacement for re-hydration [40,41].

The general assumption surrounding the milk intolerance syndrome is that it is triggered by lactose malabsorption [42,43]. However, as described in the 2010 National Institutes of Health Consensus statement on lactose intolerance, many who suffer from self-reported gastrointestinal (GI) issues display no evidence of insufficient lactase enzyme activity [44]. An alternative mechanism supported by growing evidence [45-47] is that bovine beta-cosmorphin-7 (BCM-7) (See Figure 1), derived from A1-beta casein in regular milk, but not A2-beta casein, expresses opioid receptors in the human GI tract upon digestion which may cause motility disorders, inflammation, abdominal pain and loose stools [44,48]. Furthermore, it has been speculated the interaction of lactose and BCM-7 with regular milk may exacerbate the above-mentioned symptoms [48]. Consequently, an alternative option 
for athletes who suffer from these GI discomforts with regular milk is warranted. A2 milk is a natural, biologically-occurring form of cow's milk, identical in nutrient composition to regular milk, but lacks A1-beta casein and therefore BCM-7 expression, and as such may offer a substitute [49]. However, no study to date has investigated the effects of A2 milk on EIMD following strenuous exercise.

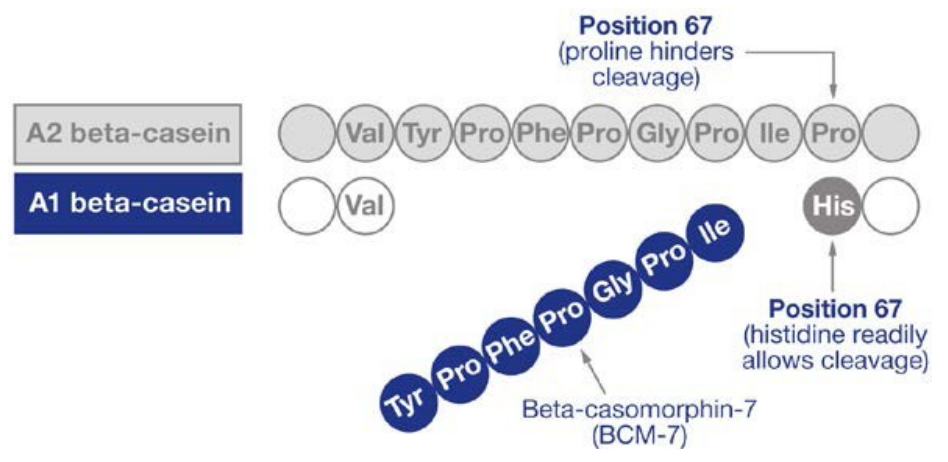

Figure 1. Structure of beta-casmorphin-7. Adapted from [48] (reproduced with permission).

Accordingly, the aim of this study was to examine whether A2 milk is equally as effective as regular milk for attenuating EIMD, following a sport-specific bout of repeated sprint exercise. Hence, the authors hypothesised that A2 milk would be as effective as regular milk for attenuating markers of EIMD. In addition, both milk supplements would be more effective than a placebo.

\section{Materials and Methods}

\subsection{Participants}

Twenty-one healthy males, who regularly competed in team-sports (Gaelic football $n=7$; soccer $n=7$; rugby $n=7$ ) were recruited to take part in this study (see Table 1 ). Sample size estimates were based on previous literature examining milk supplementation and EIMD that had shown a statistical effect [26,34]. Following institutional ethical approval (W14026049), all laboratory procedures, associated risks and benefits were illustrated both verbally and in written format, before participants provided written consent. Participants were familiarised with all laboratory procedures prior to study commencement and instructed to arrive at the laboratory in a rested state, having avoided strenuous physical activity for at least $72 \mathrm{~h}$ before testing. Participants were also instructed to refrain from exercise, nutritional supplements (whey PRO, casein PRO, branched-chain AA, creatine), caffeine, alcohol and anti-inflammatory drugs for the duration of the study. Participants were excluded if they had recently suffered from a musculoskeletal injury, were receiving prescribed medications or had an intolerance to dairy or lactose products. To minimise diurnal variation, participants were tested at the same time each day [50].

Table 1. Group subject characteristics.

\begin{tabular}{ccccc}
\hline Group & Baseline MVIC (N·m) & Age (Years) & Height (m) & Weight (kg) \\
\hline A2 milk & $685 \pm 89$ & $23 \pm 3$ & $178.8 \pm 5.1$ & $79.4 \pm 10.1$ \\
Regular Milk & $644 \pm 74$ & $23 \pm 1$ & $183.0 \pm 8.6$ & $81.4 \pm 13.1$ \\
Placebo & $606 \pm 74$ & $22 \pm 1$ & $180.7 \pm 5.5$ & $77.1 \pm 7.8$ \\
\hline
\end{tabular}

Values presented as mean \pm standard deviations (SD; $n=7$ per group). MVIC: maximal voluntary isometric contraction. No significant differences were detected between groups for any variable $(p>0.05)$.

\subsection{Study Design}

Participants were assigned to one of three independent groups, in a double-blind design. On the first day of the trial, participants performed a range of neuromuscular functional tests before the 
repeated sprint protocol. Immediately after the repeated sprint protocol, participants consumed their allocated drinks. The dependent variables (visual analogue scale, muscle soreness), countermovement jump height (CMJ), maximum voluntary isometric contraction (MVIC) and 20-m sprint were measured in the respective order prior to and 24,48 , and $72 \mathrm{~h}$ after the repeated sprint protocol (See Figure 2).

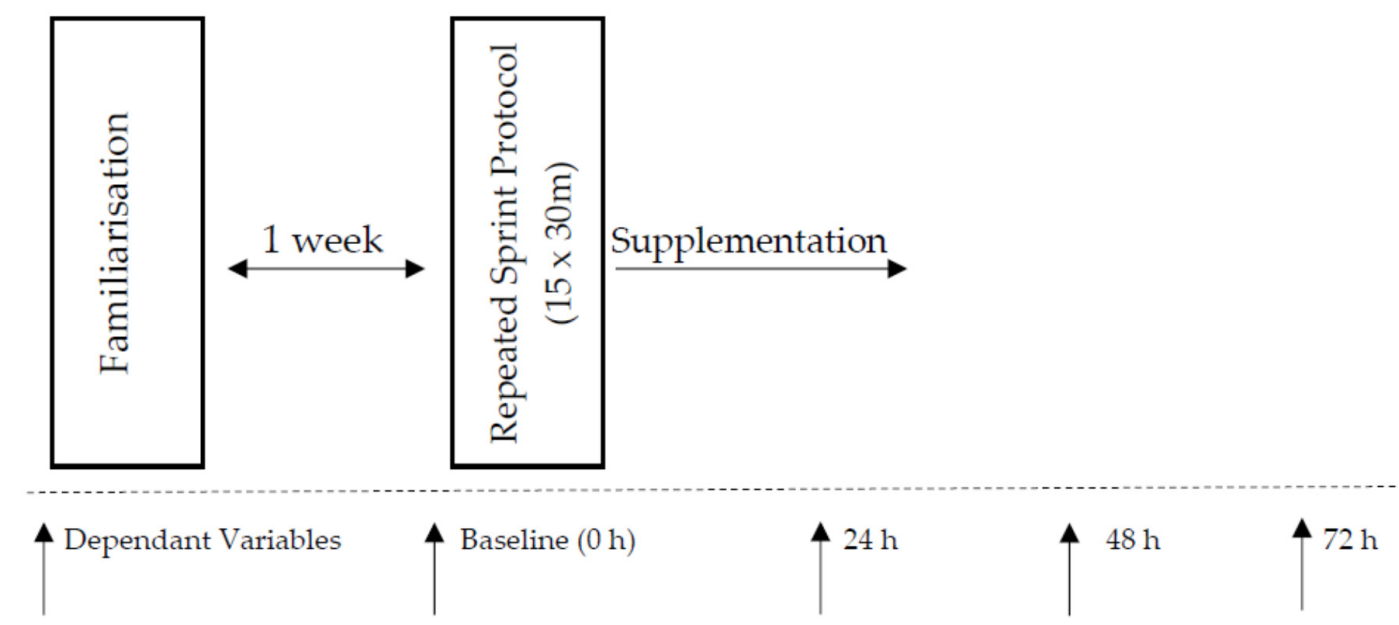

Time

Figure 2. Experimental design of study protocol.

\subsection{Nutritional Intervention and Dietary Control}

Participants were randomly but equally divided according to their baseline MVIC score ascertained at familiarisation to consume one of three drinks: A2 milk (a2 semi-skimmed milk ${ }^{\mathrm{TM}}$; The A2 Milk Company, Surrey, UK) $n=7$; regular milk (Tesco semi-skimmed milk; Tesco Stores Ltd., Cheshunt, UK) $n=7$; placebo (MyProtein maltodextrin $50 \mathrm{~g}$ mixed with water (MyProtein, Northwich, Cheshire, UK)) $n=7$ (see Table 2). Each drink was prepared in masked bottles by an external staff member who was not involved in the trial to ensure both the researchers and participants were blinded from treatments. Participants recorded their food intake for $24 \mathrm{~h}$ prior to and for the 4 trial days through the use of food diaries. Instructions were given at familiarisation on how to correctly weigh food, measure liquids, and fill in the food diaries. Throughout the trial period participants were also instructed to verbally report any GI discomforts associated with the ingestion of milk supplements to the research team.

Table 2. Macronutrient content per $500 \mathrm{~mL}$ of supplement. PRO: protein; $\mathrm{CHO}$ : carbohydrate.

\begin{tabular}{ccccc}
\hline Group & Energy & PRO & CHO & Fat \\
\hline A2 milk & $1005 \mathrm{~kJ} / 235 \mathrm{kcal}$ & $18 \mathrm{~g}$ & $24 \mathrm{~g}$ & $9 \mathrm{~g}$ \\
Regular milk & $1046 \mathrm{~kJ} / 250 \mathrm{kcal}$ & $18 \mathrm{~g}$ & $24 \mathrm{~g}$ & $9 \mathrm{~g}$ \\
Placebo & $920.5 \mathrm{~kJ} / 220 \mathrm{kcal}$ & $0 \mathrm{~g}$ & $50 \mathrm{~g}$ & $0 \mathrm{~g}$ \\
\hline
\end{tabular}

\subsection{Baseline Performance Indices}

\subsubsection{Visual Analogue Scale (Muscle Soreness)}

Participants were required to squat down to an angle equal to $90^{\circ}$ knee flexion with feet shoulder width apart and then return to the starting position. Participants then rated their perceived level of muscle soreness by marking a line on a scale between $0 \mathrm{~mm}$ (no pain) and $200 \mathrm{~mm}$ (unbearably painful). This was measured and recorded in $\mathrm{mm}$ for the pain score. See [1] for further description. 


\subsubsection{Countermovement Jump (CMJ)}

CMJ was assessed using a light timing system (Optojump, Microgate, Italy). Participants were instructed to squat down with their hands on their hips throughout and jump vertically. Participants were reminded that all efforts must be maximal. Three jumps with a 60-s rest in-between were performed with the peak jump height used for data analysis. See [39] for further description.

\subsubsection{Maximal Voluntary Isometric Contraction (MVIC)}

MVIC force of the dominant knee extensor was recorded using a strain gauge (MIE Digital Myometer, MIE Medical Research Ltd., Leeds, UK). The knee joint angle was set before each contraction at $90^{\circ}$ using a goniometer to minimise error derived from alteration in muscle length. All participants completed three isometric MVIC's of 3-s duration, separated by a $60-\mathrm{s}$ rest period. The peak MVIC from the three contractions was used for statistical analysis. See [1] for further description.

\subsection{4. $20 \mathrm{~m}$ Sprint Test}

As described elsewhere [39], participants completed three maximal effort 20-m sprints each day on an indoor running track. Participants completed the sprint from a standing start $20 \mathrm{~cm}$ behind the line. Timing gates (Brower, Draper, UT, USA) were used to record sprint time with the fastest sprint used for analysis.

\subsubsection{Repeated Sprint Protocol}

The repeated sprint protocol was based on previous studies $[3,51]$ which successfully utilised it as a method of inducing muscle damage. A 30-m section of an indoor running track was marked using cones and timing gates. A further 10-m deceleration zone was marked at the end of the 30-m section. Participants first completed a warm up consisting of $400 \mathrm{~m}$ of self-paced jogging, and a series of dynamic sprint drills including high knees, heel flicks and walking lunges, which were conducted over a measured 10-m section of the aforementioned indoor running track. This was followed by a series of three practice sprints at the participants perceived 60,80 and $100 \%$ of maximum speed. Following the warm up, participants were given $5 \mathrm{~min}$ to prepare themselves for the repeated-sprint protocol, during which time no static stretching was performed as it has been previously suggested to impair sprint performance [52]. Participants then completed $15 \times 30 \mathrm{~m}$ sprints with a 60 -s rest period in-between repetitions and were instructed to stop within the marked 10-m deceleration zone. Participants were reminded to exert maximal effort during each sprint. Strong verbal encouragement was given throughout.

\subsection{Statistical Analysis}

All data are expressed as mean \pm standard deviations (SD). Participants food diaries were analysed for macronutrient content through dietary analysis software (Microdiet v2.5, Downlee systems Ltd., Salford, UK). Independent groups were analysed using a mixed model analysis of variance (SPSS Statistics 22, IBM, Chicago, IL, USA), with three group levels (A2 milk vs. regular milk vs. placebo) and four time levels (baseline, $24 \mathrm{~h}, 48 \mathrm{~h}, 72 \mathrm{~h}$ ) to establish differences between groups. Mauchly's test of sphericity was used to check homogeneity of variance for all variables; where necessary, any violations of the assumption were corrected using the Greenhouse-Geisser adjustment. Significant effects were followed up using Tukey post hoc analysis. The alpha level for statistical significance was set at $p<0.05$ a priori. To estimate the magnitude of supplements effects, Cohen's $d$ effect sizes (ES) were calculated with the magnitude of effects considered: small (0.20-0.49), medium $(0.50-0.79)$ or large $(>0.80)$. 


\section{Results}

\subsection{Group Allocation}

Analysis revealed no difference between groups in MVIC values used for group allocation $(p=0.79)$. Dietary analysis indicated there were no differences in energy $(p=0.82)$, carbohydrate $(p=0.48)$, protein $(p=0.44)$ or fat $(p=0.56)$ intake between the groups across the five days $(p>0.05$; See Table 3).

Table 3. Mean energy and macronutrient intake for the three supplement groups over the five trial days $(p>0.05)$.

\begin{tabular}{ccccc}
\hline Group & Energy & PRO & CHO & Fat \\
\hline A2 milk & $11,984 \mathrm{kcal}$ & $510 \mathrm{~g}$ & $1604 \mathrm{~g}$ & $452 \mathrm{~g}$ \\
Regular milk & $11,879 \mathrm{kcal}$ & $571 \mathrm{~g}$ & $1390 \mathrm{~g}$ & $419 \mathrm{~g}$ \\
Placebo & $11,451 \mathrm{kcal}$ & $584 \mathrm{~g}$ & $1403 \mathrm{~g}$ & $420 \mathrm{~g}$ \\
\hline
\end{tabular}

\subsection{Evidence of Muscle Damage}

All measures of neuromuscular function (20-m sprint, CMJ height, MVIC, Muscle Soreness) showed main effects for time $(p=0.022, p \leq 0.001, p \leq 0.001, p \leq 0.001$, respectively) indicating the repeated-sprint protocol induced muscle damage.

\subsection{Effects of Nutritional Supplement}

\subsubsection{The 20-m Sprint}

There were no group effects for the 20-m sprint ( $p=0.743$ ); however, a group-time interaction effect was present $(p=0.026)$. Post-hoc analysis demonstrated group differences at $48 \mathrm{~h}$ post EIMD in A2 milk vs. PLA ( $p=0.046 ; \mathrm{ES}=1.09)$ and regular milk vs. PLA $(p=0.032 ; \mathrm{ES}=0.98)$. At $48 \mathrm{~h}, 20-\mathrm{m}$ sprint time recovered quicker in A2 (3.3 \pm 0.1$)$ and regular milk (3.3 \pm 0.3$)$ vs. PLA (3.6 \pm 0.3$)$ (See Figure 3). Relative to baseline, decrements in $48 \mathrm{~h}$ 20-m sprint time were minimised in A2 (by $0.9 \pm 3.4 \%$ ) and regular milk (by $0.8 \pm 1.2 \%$ ) vs. PLA (by $6.0 \pm 7.2 \%$ ).

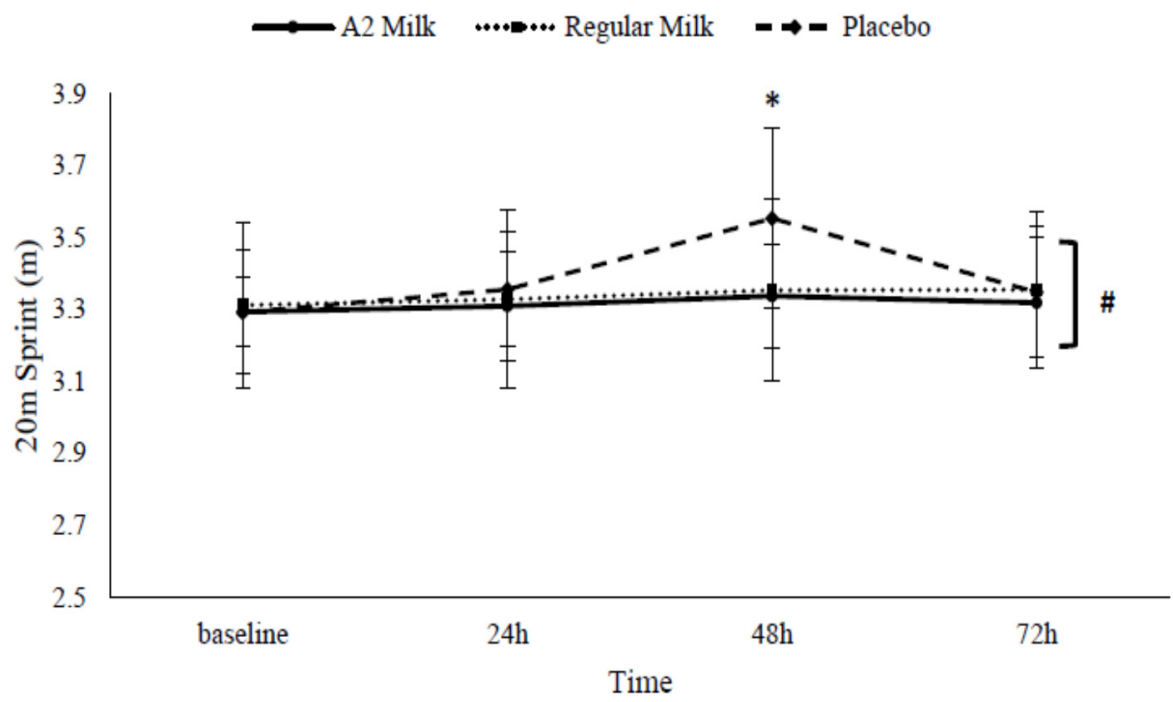

Figure 3. Change in 20-m sprint performance in response to exercise-induced muscle damage in the A2 milk $(n=7)$, regular milk $(n=7)$, and placebo $(n=7)$ groups. ${ }^{*}$ Represents group-time interaction effect $(p<0.05)$. \# Represents main effect for time $(p<0.05)$. Values presented as mean $\pm \mathrm{SD}$. 


\subsubsection{CMJ height}

A group effect showed that CMJ height appeared to recover quicker in milk treatments vs. PLA $(p=0.041)$. Although no group-time interaction effects were present $(p=0.098)$, large effect sizes $(1.42 ; 1.29)$ were again apparent at $48 \mathrm{~h}$ post EIMD, whereby CMJ recovered quicker in $\mathrm{A} 2(33.4 \pm 6.6)$ and regular milk (33.1 \pm 7.1$)$ vs. PLA $(29.2 \pm 3.6)$, respectively (See Figure 4). Relative to baseline, decrements in $48 \mathrm{~h}$ CMJ height were minimised in A2 (by $1.6 \pm 3.2 \%$ ) and regular milk (by $2.5 \pm 2.6 \%$ ) vs. PLA (by $8.8 \pm 4.4 \%$ ).

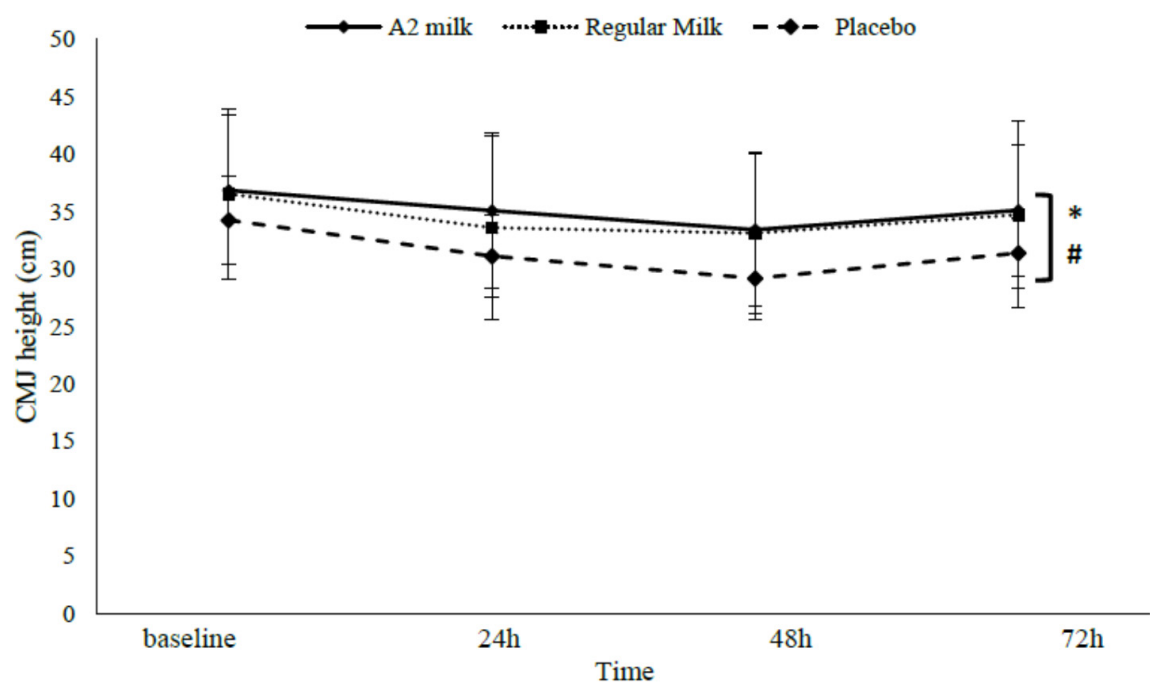

Figure 4. Change in countermovement jump (CMJ) height in response to exercise-induced muscle damage in the A2 milk $(n=7)$, regular milk $(n=7)$, and placebo $(n=7)$ groups. ${ }^{*}$ Represents group difference $(p<0.05)$. \# represents main effect for time $(p<0.05)$. Values presented as mean \pm SD.

\subsubsection{Maximal Voluntary Isometric Contraction (MVIC)}

No differences between groups ( $p=0.151)$ or interaction effects between time and group $(p=0.069)$ were observed for MVIC (See Figure 5).

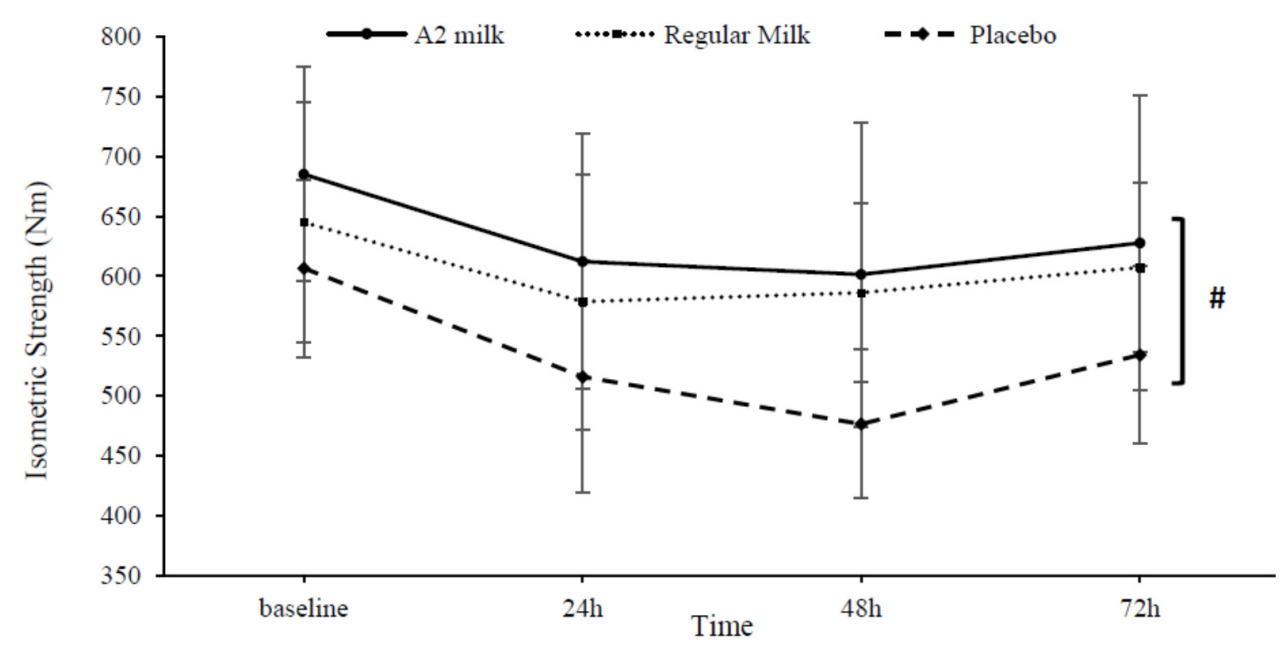

Figure 5. Change in maximal voluntary isometric contraction (MVIC) in response to exercise-induced muscle damage in the A2 milk $(n=7)$, regular milk $(n=7)$, and placebo $(n=7)$ groups. \# Represents main effect for time $(p<0.05)$. No group or interaction effects were observed $(p>0.05)$. Values presented as mean $\pm \mathrm{SD}$. 


\subsubsection{Visual Analogue Scale (Muscle Soreness)}

No differences between groups $(p=0.490)$ or interaction effects between time and group $(p=0.152)$ were observed for muscle soreness $(p>0.05)$ (See Figure 6).

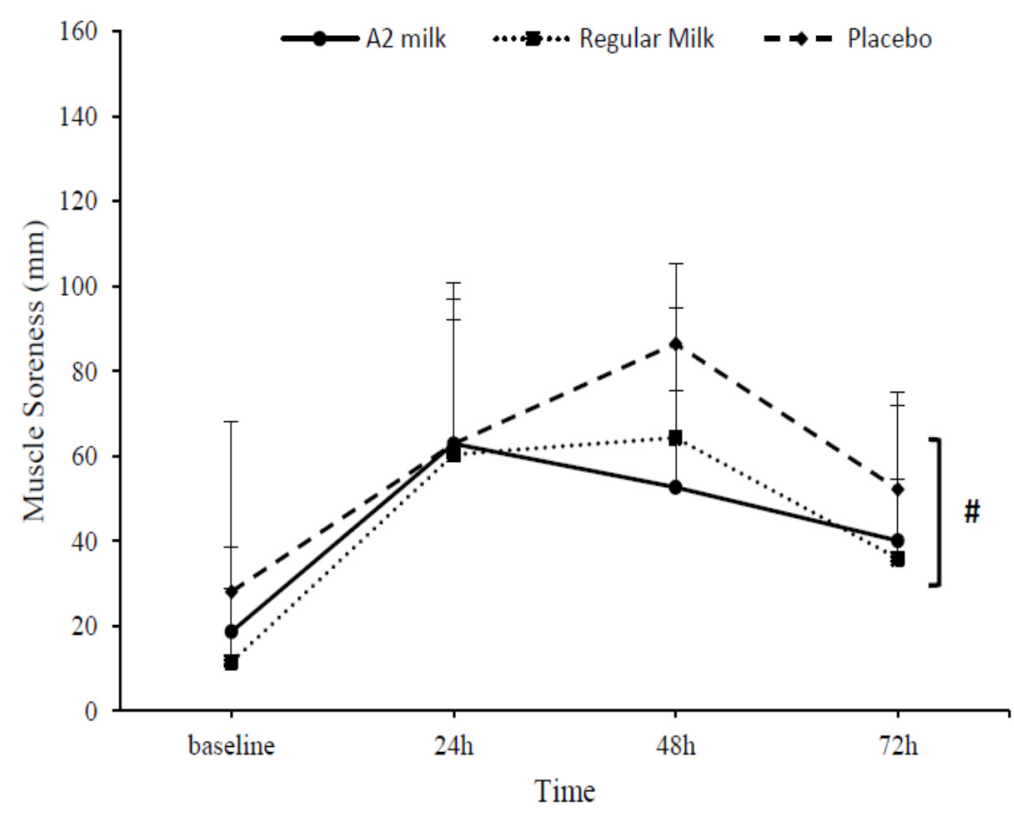

Figure 6. Change in perception of muscle soreness in response to exercise-induced muscle damage in the A2 milk $(n=7)$, regular milk $(n=7)$, and PLA $(n=7)$ groups. \# Represents main effect for time $(p<0.05)$. No group or interaction effects present $(p>0.05)$. Values presented as mean \pm SD.

\section{Discussion}

This investigation sought to examine whether A2 milk was similarly effective to regular milk for attenuating EIMD. We found $500 \mathrm{~mL}$ of $\mathrm{A} 2$ or regular cow's milk consumed immediately after the repeated sprint bout reduced decrements in 20-m sprint time (5.1 and 5.2\%, respectively) and CMJ height (7.2 and 6.3\%, respectively) $48 \mathrm{~h}$ after EIMD. Although statistical significance was not reached, MVIC was reduced to some degree with milk treatments $(p=0.069)$. These findings suggest A2 milk is an efficacious recovery beverage following EIMD, and perhaps, offers an alternative to athletes who experience GI discomfort with the expression of bovine BCM-7 derived from regular milk.

The pertinent new finding from our data show there were no differences in measures of muscle function or soreness between milk treatments. Both products were isonitrogenous, containing the same proportions of PRO ( $~ 80 \%$ casein, $\sim 20 \%$ whey), and identical amounts of $\mathrm{CHO}$ ( $24 \mathrm{~g})$ and fat $(9 \mathrm{~g})$. In addition, the AA leucine concentration in milk treatments was similar ( 1.7 g). Consequently, any effect on attenuating EIMD based on overall macronutrient ingestion would be similar. However, with regular milk there are documented negative effects of the bioactive peptide BCM-7 on GI motility [45,46], and interaction with lactose upon enzymatic digestion, which could theoretically slow absorption [48,53]. Considering this, perhaps A2 milk could offer an anabolic advantage for muscle recovery through enhanced digestion of PRO and absorption rates of AA to the muscle for protein synthesis. Nevertheless, our data show negligible effects with regard to which milk supplement was consumed, with both products similarly effective at alleviating symptoms of EIMD which was hypothesised by the authors. It may be interpreted the minor difference in PRO structure of A2 milk, is unlikely to influence its biological role in recovery from EIMD and offer an advantage to regular milk [49]. Although all participants were free from dairy intolerances prior to trial enrolment, it should be noted that compliance with milk products was satisfactory, with no verbal reporting of any discomforts. 
The benefit of A2/regular milk for male athletes corroborates previous research [34] which revealed similar improvements in muscle function $48 \mathrm{~h}$ after exercise, and additional studies examining the damage response after combined PRO-CHO supplementation [34,39,54-57]. Nevertheless, the aforementioned milk studies $[26,39,54]$ employed a laboratory-based muscle damage protocol (i.e., isokinetic dynamometer or repeated drop jumps). To ensure our findings could be more readily translated to an athletic cohort, we induced muscle damage through a validated repeated sprint exercise protocol [3], to simulate some of the movements in team-sport competition.

Several potential mechanisms may explain how A2/regular milk favourably attenuated losses in functional capacity after muscle-damaging exercise. In the present study, hyperaminacidemia following the digestion of whey/casein in milk may have initiated protein remodelling [29], primarily due to the presence of leucine [58], and the other DIAA crucial for a sustained anabolic response [59]. In addition, the synergistic intake of nutrients post-EIMD would conceivably mediate insulin release which may have suppressed exercise-induced proteolysis by dampening the activation of the ubiquitin proteasome pathway $[29,60]$. We propose that providing milk and its constituents during a period of catabolism preserved the muscle against adverse effects [61]. In turn, this may have protected contractile proteins responsible for force-generating capacity [39]. Reduced markers of pro-inflammatory cytokines in the days following EIMD have also been evident with milk supplementation [35,39]. Taken together, these mechanisms provide a feasible explanation as to how milk facilitated the maintenance of short-term dynamic muscle power output, as measured by CMJ-height and 20-m sprint performance, $48 \mathrm{~h}$ after exercise. In support, a plethora of research $[28,38,62,63]$ has documented a well-established link between myofibrillar disruption and muscle functioning. Furthermore, efficacy of milk proteins to support greater anabolism with combined whey and casein has previously been shown in comparison to ingesting either isolated protein alone [64]. Interestingly, the benefits of milk on EIMD were not apparent until $48 \mathrm{~h}$ after exercise. This may be related to PRO degradation rates not increasing until $24 \mathrm{~h}$ after exercise [38]. Various muscle biopsy studies [65-67] have shown the symptoms of ultrastructural damage become progressively worse post-exercise, peaking at $48 \mathrm{~h}$, and due to slow repair rate subside within $5-7$ days $[16,17]$.

Although milk treatments did not significantly attenuate losses of MVIC, there was a slight reduction at $48 \mathrm{~h}$ which supports existing data [22]. A possible explanation for the non-significance may be related to the differences in muscle actions during certain performance measures. For instance, assessing force production through CMJ-height and 20-m sprint speed involves eccentric-concentric muscle actions. In comparison, MVIC is measured through isometric strength production with no change in muscle length [53]. Similar reductions in loss of short-term isotonic power output following EIMD have been observed with beetroot juice ingestion, with no further beneficial effect on isometric strength $[1,68]$. Likewise, a single treatment of either cows or goats chocolate milk revealed no benefit in 2-h post-resistance exercise isometric strength assessed through mid-thigh pull performance [69]. Thus, perhaps a dynamic movement involving the stretch-shortening cycle is required to fully elucidate milk's ability to attenuate EIMD, rather than a non-lengthening muscle contraction. Alternatively, the leucine dosage of $\sim 1.7 \mathrm{~g}$ in the present study may have been suboptimal to maximise muscle protein synthesis, accounting for the non-significance. We cannot rule out this possibility considering the leucine threshold to maximise muscle remodelling post-exercise in young healthy athletes is recommended as $\sim 2-3 \mathrm{~g}[53,70]$. However, considering the positive effects milk treatments had on CMJ-height and 20-m sprint speed, this is difficult to conceive.

In line with previous research $[22,35,71]$, muscle soreness peaked $48 \mathrm{~h}$ post-exercise in the present study. However, supplementation with A2 or regular milk had no beneficial effect on attenuating soreness, in contrast to other studies $[35,39,72]$ which found soreness was reduced with milk in males. Interpreting this finding is difficult as the exact mechanism responsible for DOMS is still unknown [72]. It has been suggested the cause is due to damage to the endomysium surrounding muscle fascicles that occurs following the biphasic assault of exercise. In turn, this may result in nerve ending potentiation which has shown to correlate with increased muscle soreness [14,39]. However, milk's effects on 
this mechanism is yet to be elucidated. We postulate the milk dosages administered in the present study ( 18 g PRO in $500 \mathrm{~mL}$ ), which is slightly less than that reported in [35,72], might have been inadequate to maximise the post-exercise $\mathrm{PRO}$ metabolism response $[70,73]$ associated with perceptions of soreness.

There are some limitations in this study that need to be acknowledged. Firstly, no muscle biopsy or inflammatory blood marker was obtained to measure the mechanisms related to muscle damage and therefore we cannot directly infer how milk treatment enhanced recovery. Secondly, it is unclear if individuals who are indeed A1-protein intolerant will display the same recovery benefits with A2-milk following EIMD, as all participants reported no milk allergies prior to trial commencement. Future trials should consider these aspects and include direct measures of GI symptoms.

\section{Conclusions}

The primary implication from our study supports the use of A2 milk for athlete recovery in sports nutrition settings. We found the consumption of $500 \mathrm{~mL}$ of A2 or regular milk following repeated sprint exercise can limit decrements in muscle function in male team-sports athletes, thus hastening recovery. From a practical perspective, these findings suggest that A2 milk might offer an alternative to athletes who experience GI issues with regular milk [45]. However, this possibility needs to be investigated in athletes who are A1 beta-casein intolerant.

Acknowledgments: The authors would like to thank the participants for their dedication and hard work throughout the trial. The authors would also like to thank James Cobley for reviewing the paper prior to submission.

Author Contributions: B.K. along with T.C. and J.M. designed the protocol and collected the data. B.K. and M.J. analysed the data, B.K. wrote the full paper. F.A. and O.A. facilitated with data analysis, the preparation of the manuscript, and finalised the paper.

Conflicts of Interest: No finance was provided for conducting the study. The authors declare no conflicts of interest.

\section{References}

1. Clifford, T.; Bell, O.; West, D.J.; Howatson, G.; Stevenson, E.J. The Effects of Beetroot Juice Supplementation on Indices of Muscle Damage Following Eccentric Exercise. Eur. J. Appl. Physiol. 2016, 116, 353-362. [CrossRef] [PubMed]

2. Shirato, M.; Tsuchiya, Y.; Sato, T.; Hamano, S.; Gushiken, T.; Kimura, N.; Ochi, E. Effects of Combined $\beta$-Hydroxy- $\beta$-Methylbutyrate (HMB) and Whey Protein Ingestion on Symptoms of Eccentric Exercise-Induced Muscle Damage. J. Int. Soc. Sports Nutr. 2016, 13, 7. [CrossRef]

3. Howatson, G.; Milak, A. Exercise-Induced Muscle Damage Following a Bout of Sport Specific Repeated Sprints. J. Strength Cond. Res. 2009, 23, 2419-2424. [CrossRef] [PubMed]

4. Byrne, C.; Eston, R. The Effect of Exercise-Induced Muscle Damage on Isometric and Dynamic Knee Extensor Strength and Vertical Jump Performance. J. Sports Sci. 2002, 20, 417-425. [CrossRef] [PubMed]

5. Gilson, S.F.; Saunders, M.J.; Moran, C.W.; Moore, R.W.; Womack, C.J.; Todd, M.K. Effects of Chocolate Milk Consumption on Markers of Muscle Recovery Following Soccer Training: A Randomized Cross-over Study. J. Int. Soc. Sports Nutr. 2010, 7, 19. [CrossRef] [PubMed]

6. Tee, J.C.; Bosch, A.N.; Lambert, M.I. Metabolic Consequences of Exercise-Induced Muscle Damage. Sports Med. 2007, 37, 827-836. [CrossRef] [PubMed]

7. Howatson, G.; van Someren, K.A. The Prevention and Treatment of Exercise-Induced Muscle Damage. Sports Med. 2008, 38, 483-503. [CrossRef] [PubMed]

8. Schoenfeld, B.J. The Use of Nonsteroidal Anti-Inflammatory Drugs for Exercise-Induced Muscle Damage. Sports Med. 2012, 42, 1017-1028. [CrossRef] [PubMed]

9. Stupka, N.; Tarnopolsky, M.A.; Yardley, N.J.; Phillips, S.M. Cellular Adaptation to Repeated Eccentric Exercise-Induced Muscle Damage. J. Appl. Physiol. 2001, 91, 1669-1678. [PubMed] 
10. Cobley, J.N.; McGlory, C.; Morton, J.P.; Close, G.L. N-Acetylcysteine's Attenuation of Fatigue after Repeated Bouts of Intermittent Exercise: Practical Implications for Tournament Situations. Int. J. Sport Nutr. Exerc. Metab. 2011, 21, 451-461. [CrossRef] [PubMed]

11. Smith, C.; Kruger, M.J.; Smith, R.M.; Myburgh, K.H. The Inflammatory Response to Skeletal Muscle Injury. Sports Med. 2008, 38, 947-969. [CrossRef] [PubMed]

12. Schoenfeld, B.J. Does Exercise-Induced Muscle Damage Play a Role in Skeletal Muscle Hypertrophy? J. Strength Cond. Res. 2012, 26, 1441-1453. [CrossRef] [PubMed]

13. McHugh, M.P.; Connolly, D.A.; Eston, R.G.; Gleim, G.W. Exercise-Induced Muscle Damage and Potential Mechanisms for the Repeated Bout Effect. Sports Med. 1999, 27, 157-170. [CrossRef] [PubMed]

14. Proske, U.; Allen, T.J. Damage to Skeletal Muscle from Eccentric Exercise. Exerc. Sport Sci. Rev. 2005, 33, 98-104. [CrossRef] [PubMed]

15. Howell, J.N.; Chleboun, G.; Conatser, R. Muscle Stiffness, Strength Loss, Swelling and Soreness Following Exercise-Induced Injury in Humans. J. Physiol. 1993, 464, 183. [CrossRef] [PubMed]

16. Highton, J.M.; Twist, C.; Eston, R.G. The Effects of Exercise-Induced Muscle Damage on Agility and Sprint Running Performance. J. Exerc. Sci. Fit. 2009, 7, 24-30. [CrossRef]

17. Clarkson, P.M.; Nosaka, K.; Braun, B. Muscle Function after Exercise-Induced Muscle Damage and Rapid Adaptation. Med. Sci. Sports Exerc. 1992, 24, 512-520. [CrossRef] [PubMed]

18. Gamble, P. Periodization of Training for Team Sports Athletes. Strength Cond. J. 2006, 28, 56-66. [CrossRef]

19. McLeay, Y.; Barnes, M.J.; Mundel, T.; Hurst, S.M.; Hurst, R.D.; Stannard, S.R. Effect of New Zealand Blueberry Consumption on Recovery from Eccentric Exercise-Induced Muscle Damage. J. Int. Soc. Sports Nutr. 2012, 9, 1. [CrossRef] [PubMed]

20. Hoffman, J.R.; Ratamess, N.A.; Tranchina, C.P.; Rashti, S.L.; Kang, J.; Faigenbaum, A.D. Effect of a Proprietary Protein Supplement on Recovery Indices Following Resistance Exercise in Strength/Power Athletes. Amino Acids 2010, 38, 771-778. [CrossRef] [PubMed]

21. Byrne, C.; Twist, C.; Eston, R. Neuromuscular Function after Exercise-Induced Muscle Damage. Sports Med. 2004, 34, 49-69. [CrossRef] [PubMed]

22. Howatson, G.; Hoad, M.; Goodall, S.; Tallent, J.; Bell, P.G.; French, D.N. Exercise-Induced Muscle Damage is Reduced in Resistance-Trained Males by Branched Chain Amino Acids: A Randomized, Double-Blind, Placebo Controlled Study. J. Int. Soc. Sports Nutr. 2012, 9, 1. [CrossRef] [PubMed]

23. Macnaughton, L.S.; Wardle, S.L.; Witard, O.C.; McGlory, C.; Hamilton, D.L.; Jeromson, S.; Lawrence, C.E.; Wallis, G.A.; Tipton, K.D. The Response of Muscle Protein Synthesis Following Whole-body Resistance Exercise Is Greater Following $40 \mathrm{G}$ than $20 \mathrm{G}$ of Ingested Whey Protein. Physiol. Rep. 2016, 4, e12893. [CrossRef] [PubMed]

24. Tang, J.E.; Moore, D.R.; Kujbida, G.W.; Tarnopolsky, M.A.; Phillips, S.M. Ingestion of Whey Hydrolysate, Casein, or Soy Protein Isolate: Effects on Mixed Muscle Protein Synthesis at Rest and Following Resistance Exercise in Young Men. J. Appl. Physiol. 2009, 107, 987-992. [CrossRef] [PubMed]

25. Kirby, T.J.; Triplett, N.T.; Haines, T.L.; Skinner, J.W.; Fairbrother, K.R.; McBride, J.M. Effect of Leucine Supplementation on Indices of Muscle Damage Following Drop Jumps and Resistance Exercise. Amino Acids 2012, 42, 1987-1996. [CrossRef] [PubMed]

26. Cockburn, E.; Bell, P.G.; Stevenson, E. Effect of Milk on Team Sport Performance after Exercise-Induced Muscle Damage. Med. Sci. Sports Exerc. 2013, 45, 1585-1592. [CrossRef] [PubMed]

27. Suber, T. Dairy Protein Can Improve the Lives of Billions, Worldwide. Dairy Foods 2015, 116, 22.

28. Pasiakos, S.M.; Lieberman, H.R.; McLellan, T.M. Effects of Protein Supplements on Muscle Damage, Soreness and Recovery of Muscle Function and Physical Performance: A Systematic Review. Sports Med. 2014, 44, 655-670. [CrossRef] [PubMed]

29. Wilkinson, S.B.; Tarnopolsky, M.A.; MacDonald, M.J.; MacDonald, J.R.; Armstrong, D.; Phillips, S.M. Consumption of Fluid Skim Milk Promotes Greater Muscle Protein Accretion after Resistance Exercise than Does Consumption of an Isonitrogenous and Isoenergetic Soy-Protein Beverage. Am. J. Clin. Nutr. 2007, 85, 1031-1040. [PubMed]

30. Lysenko, E.A.; Vepkhvadze, T.F.; Lednev, E.M.; Vinogradova, O.L.; Popov, D.V. Branched-Chain Amino Acids Administration Suppresses Endurance Exercise-Related Activation of Ubiquitin Proteasome Signaling in Trained Human Skeletal Muscle. J. Physiol. Sci. 2016. [CrossRef] 
31. Greenhaff, P.L.; Karagounis, L.G.; Peirce, N.; Simpson, E.J.; Hazell, M.; Layfield, R.; Wackerhage, H.; Smith, K.; Atherton, P.; Selby, A.; et al. Disassociation between the Effects of Amino Acids and Insulin on Signaling, Ubiquitin Ligases, and Protein Turnover in Human Muscle. AJP Endocrinol. Metab. 2008, 295, E595-E604. [CrossRef] [PubMed]

32. Churchward-Venne, T.A.; Holwerda, A.M.; Phillips, S.M.; van Loon, L.J. C. What Is the Optimal Amount of Protein to Support Post-Exercise Skeletal Muscle Reconditioning in the Older Adult? Sports Med. 2016, 46, 1205-1212. [CrossRef] [PubMed]

33. Clark, M.G. Impaired Microvascular Perfusion: A Consequence of Vascular Dysfunction and a Potential Cause of Insulin Resistance in Muscle. AJP Endocrinol. Metab. 2008, 295, E732-E750. [CrossRef] [PubMed]

34. Cockburn, E.; Hayes, P.R.; French, D.N.; Stevenson, E.; St Clair Gibson, A. Acute Milk-Based protein-CHO Supplementation Attenuates Exercise-Induced Muscle Damage. Appl. Physiol. Nutr. Metab. 2008, 33, 775-783. [CrossRef] [PubMed]

35. Cockburn, E.; Stevenson, E.; Hayes, P.R.; Robson-Ansley, P.; Howatson, G. Effect of Milk-Based Carbohydrate-Protein Supplement Timing on the Attenuation of Exercise-Induced Muscle Damage. Appl. Physiol. Nutr. Metab. 2010, 35, 270-277. [CrossRef] [PubMed]

36. Cockburn, E.; Robson-Ansley, P.; Hayes, P.R.; Stevenson, E. Effect of Volume of Milk Consumed on the Attenuation of Exercise-Induced Muscle Damage. Eur. J. Appl. Physiol. 2012, 112, 3187-3194. [CrossRef] [PubMed]

37. Harber, M.P.; Konopka, A.R.; Jemiolo, B.; Trappe, S.W.; Trappe, T.A.; Reidy, P.T. Muscle Protein Synthesis and Gene Expression during Recovery from Aerobic Exercise in the Fasted and Fed States. AJP Regul. Integr. Comp. Physiol. 2010, 299, R1254-R1262. [CrossRef] [PubMed]

38. Raastad, T.; Owe, S.G.; Paulsen, G.; Enns, D.; Overgaard, K.; Crameri, R.; Kiil, S.; Belcastro, A.; Bergersen, L.; HalléN, J. Changes in Calpain Activity, Muscle Structure, and Function after Eccentric Exercise. Med. Sci. Sports Exerc. 2010, 42, 86-95. [CrossRef] [PubMed]

39. Rankin, P.; Stevenson, E.; Cockburn, E. The Effect of Milk on the Attenuation of Exercise-Induced Muscle Damage in Males and Females. Eur. J. Appl. Physiol. 2015, 115, 1245-1261. [CrossRef] [PubMed]

40. Bonci, L. Supplements: Help, Harm, or Hype? How to Approach Athletes. Curr. Sports Med. Rep. 2009, 8, 200-205. [CrossRef] [PubMed]

41. Roy, B.D. Milk: The New Sports Drink? A Review. J. Int. Soc. Sports Nutr. 2008, 5, 15. [CrossRef] [PubMed]

42. Casellas, F.; Aparici, A.; Pérez, M.J.; Rodríguez, P. Perception of Lactose Intolerance Impairs Health-Related Quality of Life. Eur. J. Clin. Nutr. 2016, 70, 1068-1072. [CrossRef] [PubMed]

43. Woodford, K.B. Devil in the Milk: Illness, Health and Politics of A1 and A2 Milk; Chelsea Green Publishing: Vermont, VT, USA, 2009.

44. Suchy, F.J.; Brannon, P.M.; Carpenter, T.O.; Fernandez, J.R.; Gilsanz, V.; Gould, J.B.; Hall, K.; Hui, S.L.; Lupton, J.; Mennella, J.; et al. NIH Consensus Development Conference Statement: Lactose Intolerance and Health. NIH Consens. State Sci. Statements 2010, 27, 1-27. [PubMed]

45. Jianqin, S.; Leiming, X.; Lu, X.; Yelland, G.W.; Ni, J.; Clarke, A.J. Effects of Milk Containing Only A2 Beta Casein versus Milk Containing Both A1 and A2 Beta Casein Proteins on Gastrointestinal Physiology, Symptoms of Discomfort, and Cognitive Behavior of People with Self-Reported Intolerance to Traditional Cows' Milk. Nutr. J. 2015, 15, 35. [CrossRef] [PubMed]

46. Ho, S.; Woodford, K.; Kukuljan, S.; Pal, S. Comparative Effects of A1 versus A2 Beta-Casein on Gastrointestinal Measures: A Blinded Randomised Cross-over Pilot Study. Eur. J. Clin. Nutr. 2014, 68, 994-1000. [CrossRef] [PubMed]

47. Barnett, M.P. G.; McNabb, W.C.; Roy, N.C.; Woodford, K.B.; Clarke, A.J. Dietary A1 $\beta$-Casein Affects Gastrointestinal Transit Time, Dipeptidyl Peptidase-4 Activity, and Inflammatory Status Relative to A2 $\beta$-Casein in Wistar Rats. Int. J. Food Sci. Nutr. 2014, 65, 720-727. [CrossRef] [PubMed]

48. Pal, S.; Woodford, K.; Kukuljan, S.; Ho, S. Milk Intolerance, Beta-Casein and Lactose. Nutrients 2015, 7, 7285-7297. [CrossRef] [PubMed]

49. Truswell, A.S. The A2 Milk Case: A Critical Review. Eur. J. Clin. Nutr. 2005, 59, 623-631. [CrossRef] [PubMed]

50. Chtourou, H.; Hammouda, O.; Chaouachi, A.; Chamari, K.; Souissi, N. The Effect of Time-of-Day and Ramadan Fasting on Anaerobic Performances. Int. J. Sports Med. 2012, 33, 142-147. [CrossRef] [PubMed] 
51. Keane, K.M.; Salicki, R.; Goodall, S.; Thomas, K.; Howatson, G. Muscle Damage Response in Female Collegiate Athletes after Repeated Sprint Activity. J. Strength Cond. Res. 2015, 29, 2802-2807. [CrossRef] [PubMed]

52. Winchester, J.B.; Nelson, A.G.; Landin, D.; Young, M.A.; Schexnayder, I.C. Static Stretching Impairs Sprint Performance in Collegiate Track and Field Athletes. J. Strength Cond. Res. 2008, 22, 13-19. [CrossRef] [PubMed]

53. Witard, O.C.; Wardle, S.L.; Macnaughton, L.S.; Hodgson, A.B.; Tipton, K.D. Protein Considerations for Optimising Skeletal Muscle Mass in Healthy Young and Older Adults. Nutrients 2016, 8, 181. [CrossRef] [PubMed]

54. Iwasa, M.; Aoi, W.; Mune, K.; Yamauchi, H.; Furuta, K.; Sasaki, S.; Takeda, K.; Harada, K.; Wada, S.; Nakamura, Y.; et al. Fermented Milk Improves Glucose Metabolism in Exercise-Induced Muscle Damage in Young Healthy Men. Nutr. J. 2013, 12, 83. [CrossRef] [PubMed]

55. Samadi, A.; Gaeini, A.A.; Kordi, M.R.; Rahimi, M.; Rahnama, N.; Bambaeichi, E. Effect of Various Ratios of Carbohydrate-Protein Supplementation on Resistance Exercise-Induced Muscle Damage. J. Sports Med. Phys. Fit. 2012, 52, 151-157.

56. Baty, J.J.; Hwang, H.; Ding, Z.; Bernard, J.R.; Wang, B.; Kwon, B.; Ivy, J.L. The Effect of a Carbohydrate and Protein Supplement on Resistance Exercise Performance, Hormonal Response, and Muscle Damage. J. Strength Cond. Res. 2007, 21, 321-329. [CrossRef] [PubMed]

57. Wilkinson, S.B. Impact of Resistance and Endurance Exercise and Ingestion of Varying Protein Sources on Changes in Human Skeletal Muscle Protein Turnover. Ph.D. Thesis, McMaster University, Hamilton, ON, Canada, 2015.

58. McGlory, C.; Phillips, S.M. Exercise and the Regulation of Skeletal Muscle Hypertrophy. In Progress in Molecular Biology and Translational Science; Elsevier: Amsterdam, The Netherlands, 2015; Volume 135, pp. 153-173.

59. Phillips, S.M.; van Loon, L.J. Dietary Protein for Athletes: From Requirements to Optimum Adaptation. J. Sports Sci. 2011, 29 (Suppl. 1), S29-S38. [CrossRef] [PubMed]

60. Dangin, M.; Guillet, C.; Garcia-Rodenas, C.; Gachon, P.; Bouteloup-Demange, C.; Reiffers-Magnani, K.; Fauquant, J.; Ballèvre, O.; Beaufrère, B. The Rate of Protein Digestion Affects Protein Gain Differently during Aging in Humans. J. Physiol. 2003, 549, 635-644. [CrossRef] [PubMed]

61. Boirie, Y.; Dangin, M.; Gachon, P.; Vasson, M.-P.; Maubois, J.-L.; Beaufrère, B. Slow and Fast Dietary Proteins Differently Modulate Postprandial Protein Accretion. Proc. Natl. Acad. Sci. USA 1997, 94, 14930-14935. [CrossRef] [PubMed]

62. Paulsen, G.; Mikkelsen, U.R.; Raastad, T.; Peake, J.M. Leucocytes, Cytokines and Satellite Cells: What Role Do They Play in Muscle Damage and Regeneration Following Eccentric Exercise. Exerc. Immunol. Rev. 2012, 18, 42-97. [PubMed]

63. Schoenfeld, B.J. The Mechanisms of Muscle Hypertrophy and Their Application to Resistance Training. J. Strength Cond. Res. 2010, 24, 2857-2872. [CrossRef] [PubMed]

64. Lacroix, M.; Bos, C.; Léonil, J.; Airinei, G.; Luengo, C.; Daré, S.; Benamouzig, R.; Fouillet, H.; Fauquant, J.; Tomé, D.; et al. Compared with Casein or Total Milk Protein, Digestion of Milk Soluble Proteins Is Too Rapid to Sustain the Anabolic Postprandial Amino Acid Requirement. Am. J. Clin. Nutr. 2006, 84, 1070-1079. [PubMed]

65. Malm, C.; Nyberg, P.; Engström, M.; Sjödin, B.; Lenkei, R.; Ekblom, B.; Lundberg, I. Immunological Changes in Human Skeletal Muscle and Blood after Eccentric Exercise and Multiple Biopsies. J. Physiol. 2000, 529, 243-262. [CrossRef] [PubMed]

66. Friden, J.; Sjöström, M.; Ekblom, B. Myofibrillar Damage Following Intense Eccentric Exercise in Man. Int. J. Sports Med. 1983, 4, 170-176. [CrossRef] [PubMed]

67. Phillips, S.M.; Tipton, K.D.; Aarsland, A.; Wolf, S.E.; Wolfe, R.R. Mixed Muscle Protein Synthesis and Breakdown after Resistance Exercise in Humans. Am. J. Physiol. Endocrinol. Metab. 1997, 273, E99-E107.

68. Clifford, T.; Berntzen, B.; Davison, G.W.; West, D.J.; Howatson, G.; Stevenson, E.J. Effects of Beetroot Juice on Recovery of Muscle Function and Performance between Bouts of Repeated Sprint Exercise. Nutrients 2016, 8, 506. [CrossRef] [PubMed] 
69. Bellar, D.; LeBlanc, N.R.; Murphy, K.; Moody, K.M.; Buquet, G. The Impact of Chocolate Goat's and Cow's Milk on Postresistance Exercise Endocrine Responses and Isometric Mid-Thigh Pull Performance. J. Diet. Suppl. 2016, 13, 560-569. [CrossRef] [PubMed]

70. Witard, O.C.; Jackman, S.R.; Breen, L.; Smith, K.; Selby, A.; Tipton, K.D. Myofibrillar Muscle Protein Synthesis Rates Subsequent to a Meal in Response to Increasing Doses of Whey Protein at Rest and after Resistance Exercise. Am. J. Clin. Nutr. 2014, 99, 86-95. [CrossRef] [PubMed]

71. Shimomura, Y.; Inaguma, A.; Watanabe, S.; Yamamoto, Y.; Muramatsu, Y.; Bajotto, G.; Sato, J.; Shimomura, N.; Kobayashi, H.; Mawatari, K.; et al. Branched-Chain Amino Acid Supplementation before Squat Exercise and Delayed-Onset Muscle Soreness. Int. J. Sport Nutr. 2010, 20, 236. [CrossRef]

72. Hatchett, A.; Berry, C.; Oliva, C.; Wiley, D.; St. Hilaire, J.; LaRochelle, A. A Comparison between Chocolate Milk and a Raw Milk Honey Solution's Influence on Delayed Onset of Muscle Soreness. Sports 2016, 4, 18. [CrossRef]

73. Moore, D.R.; Churchward-Venne, T.A.; Witard, O.; Breen, L.; Burd, N.A.; Tipton, K.D.; Phillips, S.M. Protein Ingestion to Stimulate Myofibrillar Protein Synthesis Requires Greater Relative Protein Intakes in Healthy Older Versus Younger Men. J. Gerontol. A Biol. Sci. Med. Sci. 2015, 70, 57-62. [CrossRef] [PubMed]

(C) 2017 by the authors; licensee MDPI, Basel, Switzerland. This article is an open access article distributed under the terms and conditions of the Creative Commons Attribution (CC BY) license (http:/ / creativecommons.org/licenses/by/4.0/). 